\title{
From Traditional Classroom to Programming and Design Financial Tool to Debt Restructuring with Equivalent Equations Model
}

\author{
Arturo García-Santillán* \\ Researcher Professor at Administrative-Economic Research Center Universidad Cristóbal Colón \\ Email: arturogarciasantillan@yahoo.com.mx \\ Lucía Ríos-Álvarez \\ Liaison Officer to Mexico, EDUCANDO School of Values for the Sustainable Development at UNESCO \\ Universidad Politécnica de Valencia \\ Email: Irios@educandomex.com, lurioal@doctor.upv.es, lucy2813@yahoo.com.mx \\ Milka Elena Escalera-Chávez \\ Researcher Professor at Multidisciplinary Unit of the Center Zone at Universidad Autónoma de San Luis Potosi \\ Email: milkaech@uaslp.mx \\ Teresa Zamora-Lobato \\ Third Year Doctoral Program Student at Universidad Cristóbal Colón \\ Email: teresa_zamora76@hotmail.com \\ Felipe Pozos-Texon \\ Third Year Doctoral Program Student at Universidad Cristóbal Colón \\ Email: fpozost@gmail.com
}

\section{Doi:10.5901/mjss.2015.v6n2p35}

\section{Abstract}

The Information and Communications Technology (ICT) enable the simplification of activities carried out all business and particularly in financial activities. For this purpose, in this paper we will discuss the importance of teaching financial mathematics and the importance to have a financial instrument for developing calculations in several scenarios in real time to making decision. It is described, how in a classroom would teach in the traditional system in a specific theme of mathematics, such as: "debt restructuring and modeling equivalent of the equation" Starting from the theoretical explanation, we continue with the design of financial simulator programmed into a spreadsheet.

Keywords: Financial mathematics, Teaching-learning process, Educational software, ICT

\section{Introduction}

The process in the education - learning of mathematics, has being positively influenced by the communication and information technologies. However, these technologies are design, administrated and executed by people, which means, the hand of the people still above all of them. Therefore, emerges one question, ¿it's really true that the use of communication and information technologies have positively influenced in the education-learning of the mathematics? Probably the answer could be yes, and actually the use of new information technologies has significantly promoted the education-learning process. How we may view this process as a first construct: (See figure 1). 
Figura 1. Teaching-learning model through the use of ICT

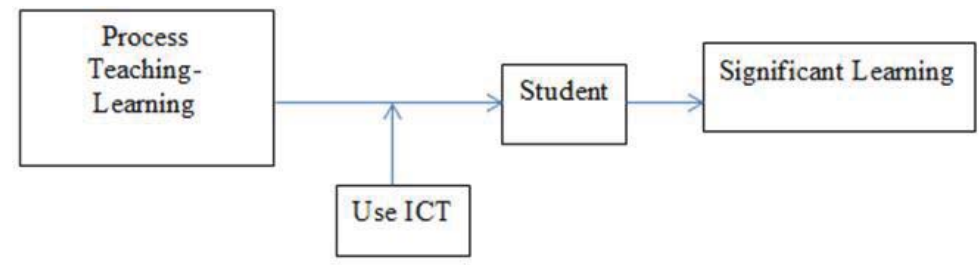

Source: adapted from García and Edel (2008)

The variables in the process E-A-E are: The process (education -Learning), the media (the ICTS), the product (significant learning). However in the process of the traditional education -learning, one of the main elements is the teacher, therefore this variable should be considered in the model. Whit this consideration, now the model has to be reconsidered as a new construct: (See figure 2)

Figura 2. Teaching-learning model through the use of ICT

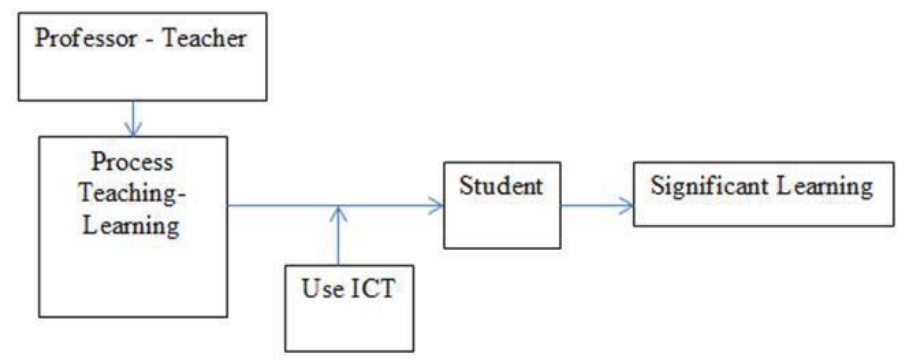

Source: adapted from García and Edel (2008)

Into traditional learning, the teacher has become the main factor as an element capable of developing new knowledge in the student. It certainly is the person who has the experience and the knowledge, as well as being the student guide. That is, starting from the explanation and the activities that the professor provides in class, the students they develop in the practice this newly acquired knowledge. But what happens before this process?, Does the student tend to reject mathematics, so it is necessary to integrate new variables for the teaching and learning process, which could make it attractive to the student. This element could be a spreadsheet, in which it's possible to design a series of calculus simulations, which allows performing simulations with mathematical exercises. (Garcia-Santillán, Escalera-Chávez, Córdova-Rangel and López-Morales, 2014, Nies: 2007).

\subsection{The simulation and the modeling in education-learning}

Simulation is the hardware and software configuration in which, through some computational algorithms, can reproduce the behavior of a given process. In the process, the actual situations are replaced by other, artificially designed. With this may can be learned about the actions resulting from this simulation process and may be transferred to real-life situations with equal efficiency.

In this activity is accumulated not only theoretical information, is also put into practice. The simulators are constituted by a procedure, which helps for the creation of concepts and knowledge building in general. It is carried out for application to this new context in which, for some reason, the student cannot be accessed from the methodological context in which knowledge is developed. In this digital era without a doubt, the potential in the use of computers and software in the educational field is to recognize. The technological advances allow to the students, --through the computer and the simulation-, addressing learning situations that, for some physical and economics restrictions, could be difficult to experiment in a natural environment or in a laboratory.

The simulation allows construction of ideal scenarios, as well the manipulation of the variables to observe its impact in certain phenomena, or just for give to the apprentice a teaching resort for the replica of the learned theories. 
The influence of the simulation in the educational process have a broad spectrum, this last is based in three main features:

$\checkmark$ it's motivational, because it allows the representation of study phenomena that potentially capture the attention and interest of the student,

$\checkmark$ Is a provider element in the learning, because the student interacts with simulation, helping the understanding of knowledge trough the discovery and understanding of the phenomena, system or simulated process.

$\checkmark$ Finally

$\checkmark$ It is an element to reinforce, because allows to the apprentice (student), the application of the acquired knowledge, and therefore the generalization of it.

Simulation as a teaching strategy, allows access to the building of models, in a real situation. The use of simulation in the education process, according to Abello, Lopez and Sara (2003) allows the building of scenarios in an environment close to reality, but in a controlled and safe way, regarding certain difficult, expensive and dangerous aspects which in the reality, could be difficult to achieve. With the simulation it is possible replicate the experience many times as necessary, at minimal cost.

Furthermore, the simulation in the education process allows alteration of the times with discretion. It is able to take decisions in real time, which in other contexts would not be possible. In Figure 3 we can see an example.

Figure 3. Several uses of the simulators in economic activities

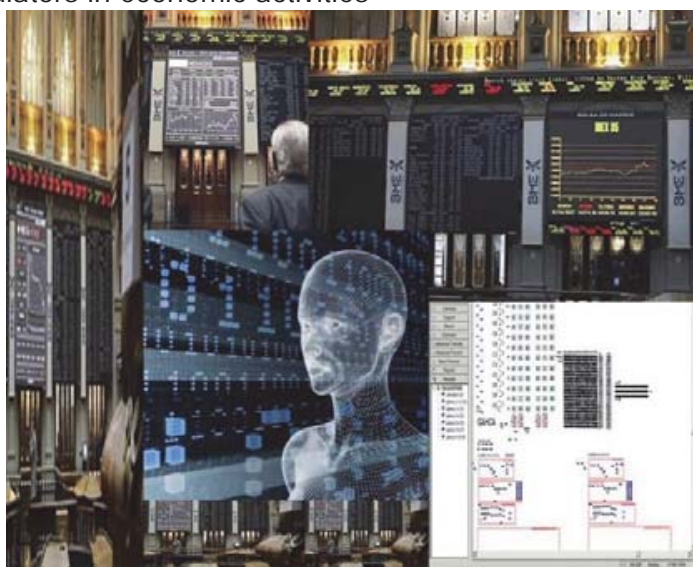

Source: Google-images (2014)

Another benefit of simulation according to Abello et al (2003) is those related to the use of images, creating a graphical view of the situation where the simulation takes place. In the same way, the simulation as a tool in the educational process makes it easy to create changes and alterations in the simulation model, and allows us to observe the behavior of the users and the effects on these causes, as well as the practice of existing procedures and experiment with this new policy and decision rules. With these arguments, it is now necessary to explain the theoretical and empirical arguments.

\section{Theoretical Framework}

Nowadays a tendency that there has been more strongly in education is into the mathematics teaching, and to this end, has been by using the technology (ICT) (Goldenberg, 2003). Inside this field, the use of the spreadsheet in computers has enabled a major step forward in this topic.

Within this field, the use of the spreadsheet in computers has allowed a significant step forward in this area. In this regard, we may say as precedent of mathematical calculations in spreadsheet, which from 1979 Dan Bricklin design "VisiCalc", using for this, an Apple II computer. This fourth generation software has allowed the development of financial projections automatically, only with the manipulation of some values.

Based on this, the management and business sector had been favored in time and cost, because now, the financial decisions are based in the determination of the best alternative which a financial simulation produces. The success in the use of the spreadsheet, is based in the experience of the professionals who handle this software, but besides that, they can know the deep problems of the company, whit this, they can be solved through the mathematics.

Other important arguments on this issue, it is indicated by Moursund (2003) and Lewis (2007) who have exposed 
different positions, at least it would seem. Firstly Moursund said that in real life there is a strong contrast in the field of education, ie, the introduction of ICT in teaching and learning at the basic level and medium, focuses more on what the tool can develop rather than be resolved. He also noted that in the case we should solve management problems in the exact and social sciences, as well as in other fields of knowledge, the spreadsheet provides a good environment for modeling these problems.

Research suggests that the students, who are faced with the topic functions using a spreadsheet and graphical tools, achieve greater understanding than those who did in a traditional way. Furthermore, the use of computers helps to support student interest to complete assignments that are tedious whether they are carried out with pencil and paper (SRI International, 2000).

Moreover, Lewis (2007) emphasizes the importance of using the spreadsheet and engagement so that teachers should encourage the use of it, because it could in a significant way contribute something to the process of teaching and learning, as well as the mathematics program. Strengthens this argument saying that the spreadsheet is a powerful tool for learning and developing skills which lead students to:

a) -Organize data (sort, categorize, generalize, compare and highlight the key elements),

b) - Perform different types of graphical interpretation and analysis,

c) - Use graphics to reinforce the concept of percentage,

d) - Use specific visual elements with a view to exploring abstract mathematical concepts (visual and spatial intelligence),

e) - Discover patterns,

f) - Understand basic math concepts such as counting, addition and subtraction,

g) - Stimulate the mental abilities in the superior order by using formulas for conditional answer questions like "if ... Then " and finally ----

h) - Solving problems and using formulas to manipulate numbers, exploring how and what formulas can be used in a certain problem and how to change the variables that affect the outcome. "

In Figure 4, shows the process of logical functions generated by the use of the spreadsheet; this could encourage planning for designing the session with the application of ICT. That is, it is the most important action between the teacher, who teaches in the traditional class session and migration toward the use of the spreadsheet in the teaching of mathematics.

Figure 4. Functions Worksheet

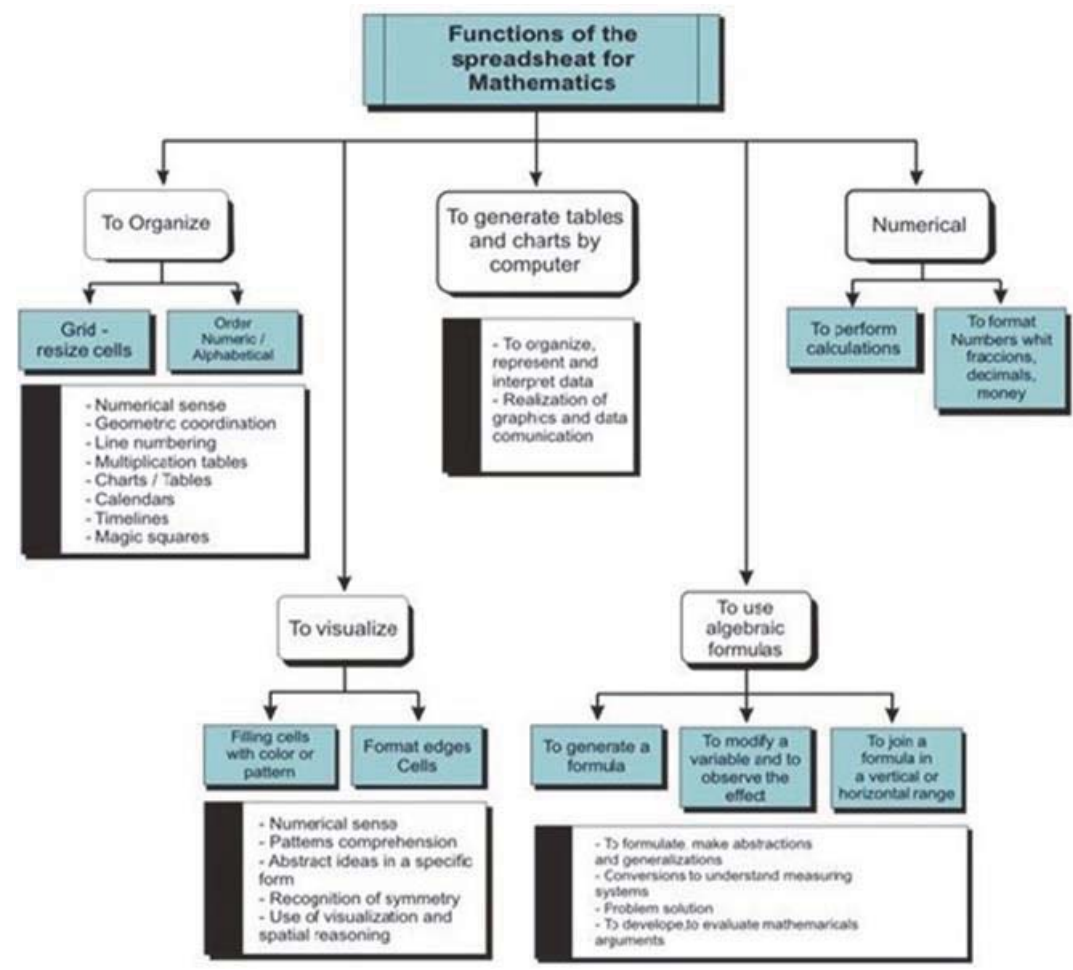

Source: Lewis (2007) 
Finally we can include the history of mathematics in the classroom, like say Fauvel (1991), Clinard (1993), Bidwell (1993), Murugan (1995), Barbin (1997), Furinghetti (1997), Ernest (1998) and Jonasse (1998), García and Edel (2008) and García-Santillán et al (2014) as a methodological tool that could be help to learning.

\section{Programming in a Spreadsheet}

The usefulness of ICT, and the benefit that may be obtained from this, are given starting from the development of a plan for the session that will be held on a specific topic of financial mathematics, i.e., starting from the development plan sessions of the course, as well, the didactic strategies to be used in the mathematics course.

The application of ICT in the teaching process is based on the programming that is carry out in spreadsheets, as an option the program Excel of Microsoft Office. With the use of this tool, beyond making easy explanation of the math topic within the learning sessions, also will design a simulator, which helps as a calculation tool for students to develop their skills, both technological and numerical (as evidence of the product in the session).

This fact aims to demonstrate that the mathematics be one of the sciences that are more susceptible to rejection by students in the teaching-learning process, the use of ICT could be an influential element in the liking and acceptance of mathematics by the students who are training in the classroom. But, how is a session in a traditional session class? At fallowing, we develop one of the issues in mathematics course.

\section{The Topic "Equivalent Equations to Debt Restructuring"}

One of the topics addressed in the course of financial mathematics is the equivalent equations. This topic aims to that starting from a set of equations; we may carry out the calculation for renegotiating debt. Firstly we need to apply a formula that allows us to determine the amount of each payment (depending on the number of agreed payments) and also re-evaluate the original debt and certainly may be establish the new payment dates within the new payment scheme.

To do this must be considered the next steps in the renegotiation (Pastor, 1999; García-Santillán et al 2014)

1. Identify a date with which we can compare the operations to perform, which we will call focal date.

2. Calculate the value of the debt at the focal date with the formula $V_{O D}$ (Value of the Original Debt).

3. Calculate on the basis of the focal date, the provider payment options.

4. Finally, determine how much is the amount of each payment renegotiated through the formula $V_{N S}$ (Value of the New Scheme).

In summary, the proposed equivalent equation model is useful to examine the three moments of the restructuring: valuing of the original debt, determining the new payment scheme, and computing new payments. Therefore, in equivalent equations are used the next formulas:

Hence, to valuation of debt $\mathrm{V}_{\mathrm{OD}}$ :

With compound interest, which include capitalizations: Considering that most of the promissory note are expired, other is in the focal date and other document which are not yet expired

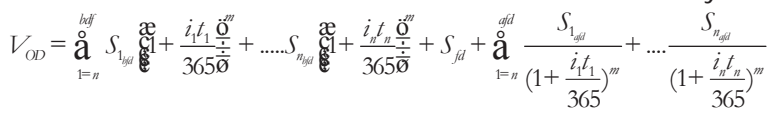

Following the mathematical model, now it's necessary to design a timeline for establishing the three moments (see figure 5): before the focal date (bfd), in the focal date ( $f d)$, and after focal date (afd).

Figure 5. Timeline Value of the Original Debt: ${ }^{V_{O D}}$

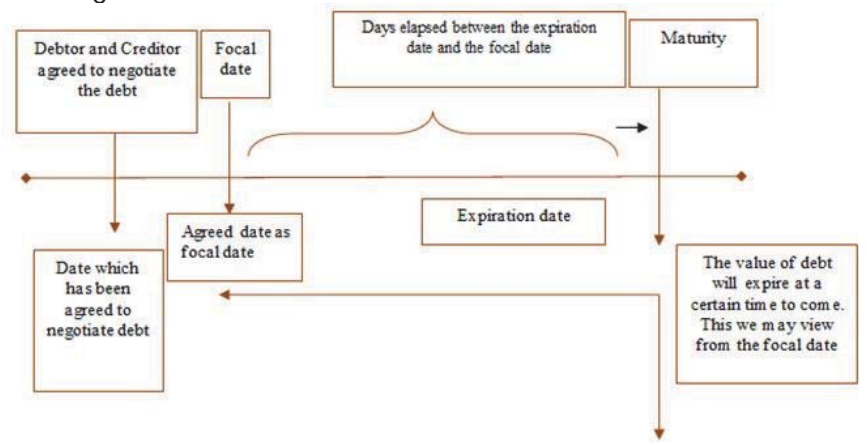

Source: own 
The elements for determination the value of the new scheme: $V_{N S}$ are: the interest rates or discount in the renegotiation among debtor and creditor is: $i_{1} \ldots$ in the time $t_{1} \ldots . . . t_{n}$, the obligation before the focal date $S_{1 b f d}$ (from 1 to $n$ ), in the focal date $S_{f d}$ and the obligations after the focal date $S_{1 \text { afd }}$ (from 1 to $n$ ).

The formula of model of the New Debt, with compounded interests' rate accurate, is as follows:

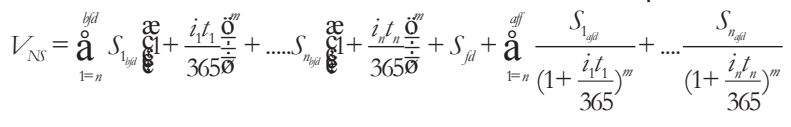

To substitute: $S_{1_{b f}} S_{f f}$ and $S_{1_{a f f}}$ by $X$

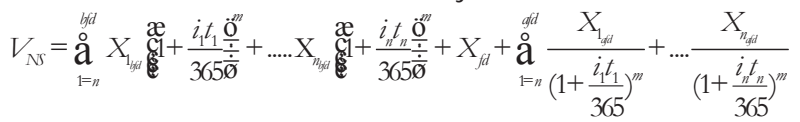

Again is substituted: $X_{1, f f} X_{f f}$ and $X_{1, f f}$ by the unity to obtain the coefficients

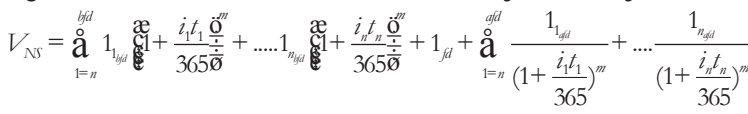

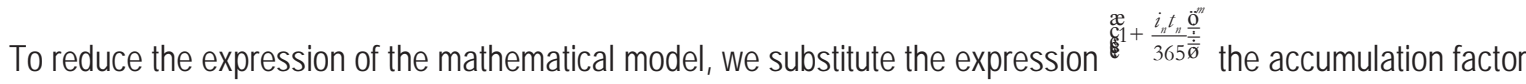
for $(\mathrm{Fa})^{m}$ resulting in the next expression:

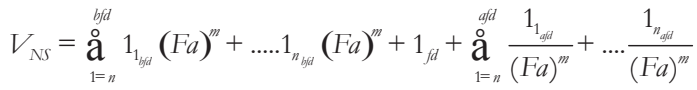

Again if we identified the payments coefficients: before the focal date, in the focal date and after the focal date like: $C_{b f d}, C_{f d}, C_{a f d}$

We obtain the expression:

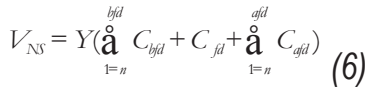

Substituting, we obtain the model expression that allows getting the amount of each payment (the new promissory notes):

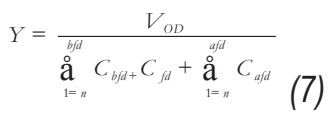

Where:

$Y=$ Value of each pay (the new promissory notes),

$V_{O D}=$ Value of the original debt, previously valued,

$\sum C_{b f d}=$ Sum of the payments coefficients before focal date,

$C_{f d}=$ Payments coefficients in the focal date.

$\sum C_{\text {afd. }}=$ Sum of the payments coefficients after the focal date.

The new scheme, from the renegotiation whit " $Y$ " equal payments on different dates (before to the focal date, in the focal date and after the focal date), may be seen in a timeline:

Figure 6. Timeline Value of the New Scheme: $V_{\mathrm{N}}$

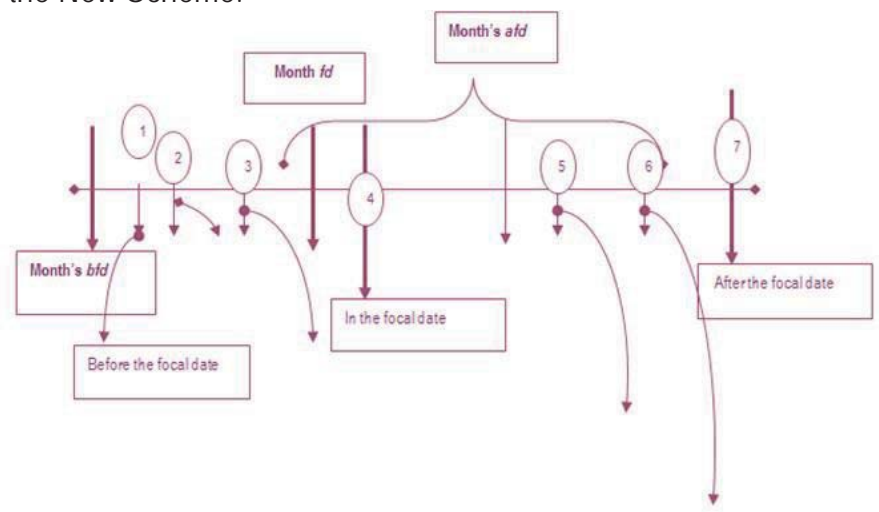

Source: own 


\section{Programing in spreadsheet}

After explained and practiced each subject of Financial Mathematics, the following step now is that the student designs his groups from the formulas used in the subject, being in this case equivalent equations with simple interest and compound interest. The cover is designed and inserts the spreadsheets for any formula that we will use.

\section{Process of Education Learning through Technology}

Step 1: The modalities are established (covers)

Figure 7. Simulator covers (In several languages-Spanish-English, French)
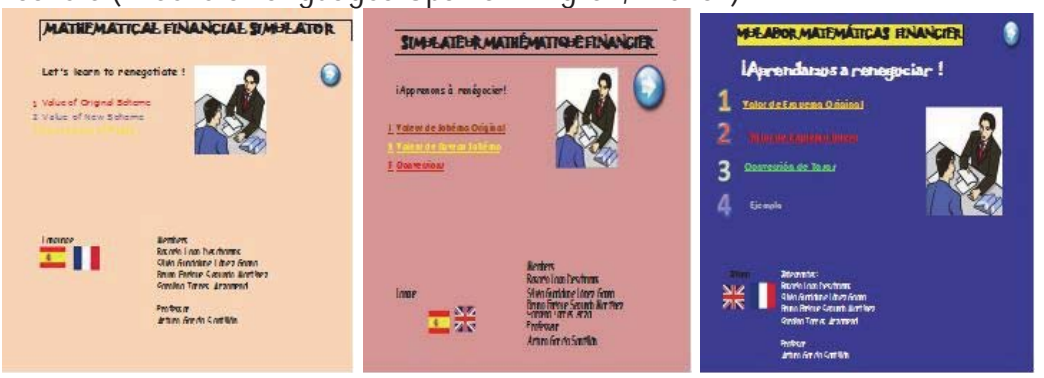

Source: own

Step 2: The programming in spreadsheet of any formula, for example, to obtain $V_{O D}$, we should programming the output cell as show in the next formula:

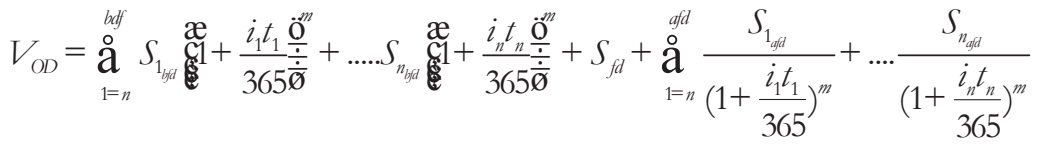

In Spreadsheet:

$=$ M6 $+($ F11/POTENCIA $(1+($ I11/12),L11))+(F13/POTENCIA(1+(I13/12),L13))+(F15/POTENCIA $(1+($ I15/12),L15))+(F1 7/POTENCIA(1+(I17/12),L17))+(F19/POTENCIA(1+(I19/12),L19))+(F21/POTENCIA(1+(I21/12),L21))+(F23/POTENCIA(1 $+($ I23/12),L23))+(F25/POTENCIA(1+(I25/12),L25))+(F27/POTENCIA(1+(I27/12),L27))+(F29/POTENCIA(1+(I29/12),L29)) +C11*POTENCIA(1+(I11/12),L11)+C13*POTENCIA(1+(I13/12),L13)+C15*POTENCIA(1+(I15/12),L15)+C17*POTENCIA( 1+(I17/12), L17)+C19*POTENCIA(1+(I19/12),L19)+C21*POTENCIA(1+(I21/12),L21)+C23*POTENCIA(1+(I23/12),L23)+C 25*POTENCIA(1+(I25/12),L25)+C27*POTENCIA(1+(I25/12),L25)+C27*POTENCIA(1+(I27/12),L27)+C29*POTENCIA(1+( I29/12),L29)

Payment value:

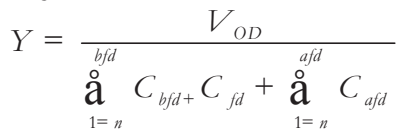

In Spreadsheet:

$=\mathrm{SI}(\mathrm{L} 20=0,0,(\mathrm{M} 20 / \mathrm{L} 20))$

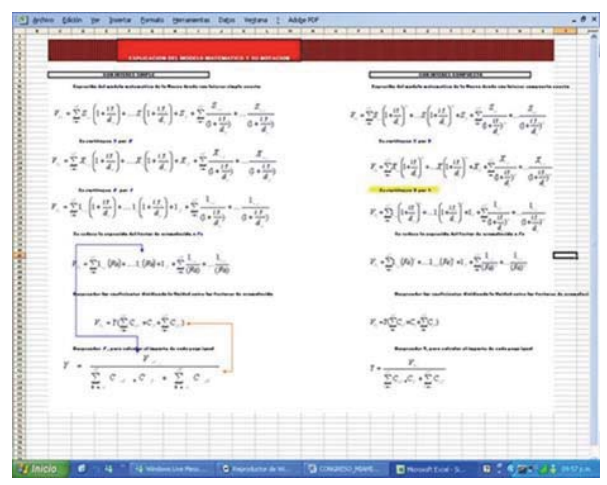


The result may be seen in the simulator which has been designed in spreadsheet (see Figure 7)

Figure 7. Value of Original Debt and Value of New Scheme
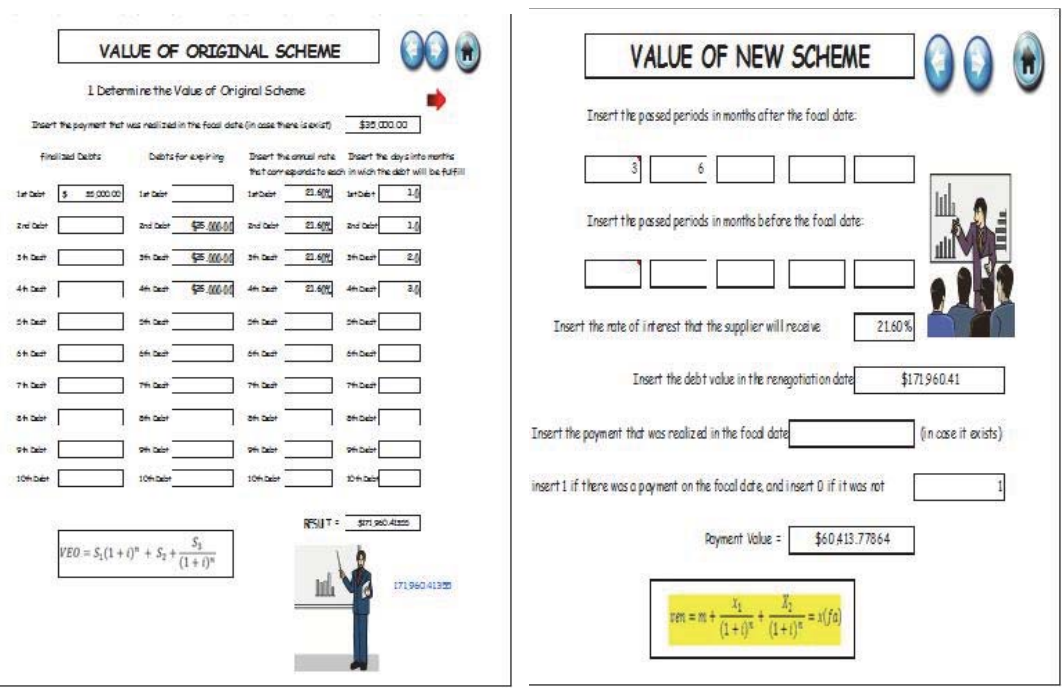

\section{Conclusion}

A significant trend in the field of teaching of mathematics is given through the use of the ICT.

That is, computing platforms have opened new avenues in the education, with the specific case in the teaching of mathematics. Some studies provide evidence that allows us to say that people, nowadays obtains better results every time, in both comprehension and developing the skills of mathematical functions, with the use of the spreadsheet and the technologies, all this in comparison to students who conducted the process of education and learning in the traditional system. ${ }^{1}$

There are several applications which ICT have given to humanity in different areas in which are utilized. For the case of this studio, we have focused on the teaching of financial mathematics and how, starting from ICT, may be developed tools that allow the manipulation of variables, either in mathematical information or data used for the development mathematical formula or model. With the graphical representation, the financial modeling and other attributes of this application, is what offered by ICT to the field of education for the development exercises.

As has been mentioned, we know that some mathematical exercises are very complexes to solve manually, using only paper and pencil. In the same way, it is necessary to break paradigms and old customs in the education learning process, and a particular way, in the mathematics teaching-learning process.

Frequently has been recommended that the teacher design his session plan supported by the computing technologies, being the specific case, the introduction of the spreadsheet. In the base of the proposed model (Figure 1 and 2) the variables are: the teaching-learning process, the tool (the use of the ICT, specifically the spreadsheet) and the product (the significant learning).

In both cases the student is the subject, and in the model b (figure 2) is integrated an important variable, being this, the professor or teacher. Being this last one, the change agent through which, the migration generated from the traditional education system of the mathematics, towards the education learning system based in the ICT application, being the specific case the use of the spreadsheet (in excel for example).

Finally we can say according to what they refer García-Santillán; Escalera; Camarena and García (2012), that even if the mathematics has been a recurring theme that is difficult for the student, it is also true that when technology is present in the process of teaching and learning the environment change. In type workshop classroom where is conducted the teaching of mathematics, the place becomes a pleasant space for the student, when there is a reciprocal relationship with a computer.

${ }^{1}$ SRI International, "A Review of Research on Computer-Based Tools (Spreadsheets, Graphing, Data Analysis, and Probability Tools), with an Annotated Bibliography" www.sri.com/policy/ctl/assets/images/Tools_review.pdf. 
Moreover, it is important to emphasize what Garcia-Santillan et al (2012) report about limitations of the study, that is, that we should not generalize from the results. Into different levels of education it is not common that the technology is used in the teaching of mathematics in the different educational levels. In fact, in the public institutions in middle and higher level means is less technology investment than in private ones universities, which leads us to think in the same way, that there are more possibilities of the utilization of this tool in the teaching of math in private institutions.

\section{Acknowledgement}

The authors are very grateful to the Universidad Cristóbal Colón, EDUCANDO School of Values for the Sustainable Development at UNESCO (Mexico), Universidad de Guadalajara and Universidad Politécnica de Valencia for all helping and support

\section{References}

Abello, C.; López, L. y Sara, A.M. (2003). Sistemas de simulación educativa, interactiva y digital en la formación de conductores y asesores. Military Review, July-August. Retrieved from: http://usacac.army.mil/cac/milreview/spanish/JulAug03/argentina.pdf

Barbin, E. (1997) "Histoire et enseignement des mathematiques: Pourquoi? Comment?". Bulletin AMQ, 37(1): 20-25, March.

Bidwell, J. (1993) "Humanize Your Classroom with the History of Mathematics." The Mathematics Teacher. An Official Journal of the National Council of Teachers of Mathematics, 86(6): 461-64, September.

Cabero, J. y otros (2004): "Las herramientas de comunicación en el "aprendizaje mezclado", Pixel-Bit. Revista de medios y educación, 23, 27-41.

Clinard, M. (1993) "Enseignement et histoire des mathematiques." Plot. Bulletin des Regionales APMEP de Poitiers, Limoges et Orleans-Tours. (64-65): 8-11, December.

Ernest, P. (1998). "The history of mathematics in the classroom." Mathematics in School, 27(4): 25-31, September.

Fauvel, J. (1991) "Using History in Mathematics Education." For the Learning of Mathematics, 11(2): 3-6, June.

Fauvel, J. y Van Maanen, J. (1997) "The role of the history of mathematics in the teaching and learning of mathematics. Discussion document for an ICMI study (1997-2000)." Zentralblatt fuer Didaktik der Mathematik, 29(4): 138-140, August.

Furinghetti, F. (1997) "History of mathematics, mathematics education, school practice: case studies in linking different domains." For the Learning of Mathematics, 17(1): 55-61, February

Furinghetti, F. y Somaglia, A. (1997) "Storia della matematica in classe". L'Educazione Matematica, 18(1): 26-46, February-May.

Furinghetti, F. y Somaglia, A. (1998) "History of mathematics in school across disciplines." Mathematics in School, 27(4): 48-51, September.

García-Santillán, A.; Escalera, M.; Camarena, P. \& García, A. M. (2012). Structural equations modeling to measure variables involved in the interaction between mathematics and computer: an empirical study in undergraduate students. International Journal of Humanities and Social Science Vol 2, No. 24 special issue December 2012 pp 6-13

Garcia and Edel (2008): Education-learning of the financial mathematics from the computer science platforms. (Simulation with ICT) Application of information and Communications Technologies (ICT) in education-learning process. Annual Meeting Nova Southeastern University "Beyond the Classroom" Fischler School Of Education \& Human Service. NOVA EDUC@2008. March 17 to 19, 2008. Miami Beach, Florida USA.

García-Santillán, A.; Escalera-Chávez, M.; Córdova Rangel, A. and López-Morales, S. (2014). The Golden Trilogy in the Teaching-Learning Process. Turkish Online Journal of Educational Technology, Vol 13 (3) July 2014 pp. 138-147. (Scopus Indexed) http://www.tojet.net/articles/v13i3/13314.pdf

Goldberg, P.: (2003). Thinking (and talking) About Technology in Math Classrooms. Publicado por Education Development Center, Inc. http://www2.edc.org/Published by EDUTEKA: September 6 / 2003.

Gómez, D. (1998). Tecnología y educación matemática. Revista Informática Educativa. Vol. 10. № 1. Colombia.

Jonassen, D., Pech, K. y Wilson, B. (1998): Learning with technology. A constructivist Perspective, Prentice may Upper Saddle River (NJ).

Katz, V. (1997) "Some ideas on the use of history in the teaching of mathematics." For the Learning of Mathematics, 17(1): 62-63, Feb.

Lewis, P.: (2003) "Spreadsheet Magic" La magia de la hoja de cálculo Publicación de este documento en EDUTEKA: Septiembre 20 de 2003. Retrieved from: http://www.eduteka.org/HojaCalculo2.php.

Moursund, David; "Editorial: The Spreadsheet"; Revista Learning \& Leading with Technology; volùmen 26, número 5. Retrieved from: http://www.iste.org/LL/

Murugan, U. (1995) "Using history of mathematics in the senior primary phase." Pythagoras, (38): 7-13, December.

Nies, M. (2007) "Cómo utilizar las hojas de cálculo para resolver ecuaciones", Traducción al español realizada por EDUTEKA del artículo original "Using Computer Spreadsheets to Solve Equations" escrito por Margaret L. Nies y publicado en el Número 3 del Volumen 26 de la revista Learning \& Leading with Technology (http://www.iste.org). Retrieved from. http://www.eduteka.org/ HojaCalculo1.php

Pizzamiglio, P. (1992) "Ruolo didattico della storia della Matematica. Parte I. La storia della Matematica a servizio della didattica." IMSI, 15(5): 287-300.

Pizzamiglio, P. (b, 1992) "Ruolo didattico della Storia della Matematica. Parte II. La comprensione storica della matematica come finalita' didattica". IMSI, 15(5): 475-491.

Russ, S. (1991) "The Experience of History in Mathematics Education." For the Learning of Mathematics, 11(2): 7-16, June.

SRI Internacional, "A Review of Research on Computer-Based Tools (Spreadsheets, Graphing, Data Analysis, and Probability Tools), with an Annotated Bibliography" Una Revisión de Investigaciones sobre Herrameintas basadas en Computadores. This document is part of the project MathLab. January 2000,

Toumasis, C. (1995) "Let's put history into our mathematics classroom." Mathematics in School, 24(2): 18-19, March. 14 